\title{
Antioxidant activities of methanolic extract and its fractions of Baccaurea racemosa and Macaranga subpeltata leaves
}

\author{
${ }^{1,2}$ Widodo, H., ${ }^{3}$ Sismindari, ${ }^{4}$ Asmara, W. and ${ }^{4,5 *}$ Rohman, A \\ ${ }^{1}$ Centre Study of Biotechnology, Gadjah Mada University, Yogyakarta 55281 Indonesia \\ ${ }^{2}$ Medicinal Plant and Traditional Medicine Research and Development Centre (MPTMRDC) - NiHRD RI, \\ Indonesia \\ ${ }^{3}$ Faculty of Pharmacy, Gadjah Mada University, Yogyakarta 55281 Indonesia \\ ${ }^{4}$ Department of Microbiology, Faculty of Veterinary Medicine, Gadjah Mada University, Yogyakarta 55281 \\ Indonesia \\ ${ }^{5}$ Institute of Halal Industry and Systems (IHIS), Gadjah Mada University, Yogyakarta 55281 Indonesia
}

Article history:

Received: 2 July 2019

Received in revised form: 8 August 2019

Accepted: 12 August 2019

Available Online: 26 August 2019

\section{Keywords:}

Macaranga subpeltata,

Baccaurea racemosa,

Antioxidant activity,

Flavonoid,

Phenolic compound

DOI:

https://doi.org/10.26656/fr.2017.4(1).144

\section{Introduction}

Reactive oxygen species (ROS) is indispensable in many biological processes, mainly during cell differentiation, defense mechanism, immunity, etc. (Baunthiyal et al., 2017), therefore ROS is produced in normal metabolic reaction (endogenous ROS) and is maintained at physiological levels by several endogenous antioxidant systems. In addition, exogenous ROS may be generated from environmental pollutants, excessive alcohol consumption, radiations exposure, viral and bacterial infections, and others (Cacciapuoti, 2016). However, a condition in which ROS are excessively generated, oxidative stress is going to be inevitable causing multiple cellular compartments damage, cell injury or cell damage. The oxidative stress, triggered by the imbalance between oxidants and antioxidants, eventually leads to many degenerative and chronic diseases in human (Gangwar et al., 2014; Matschke et al., 2019).

Any molecules capable of retarding or preventing the oxidation of other molecules are considered as an antioxidant (Ali et al., 2013). Oxidation produces free radical reactions that highly reactive species which contains one or more unpaired electrons in their outermost shell (Mamta et al., 2014). Antioxidants supplied in a diet are needed to counter the undesirable effects of oxidative stress by various mechanisms such as scavenging the active free radicals, depressing the active 
species formation, sequestering metal ion, inducing biosynthesis and enhancing the activity of endogenous antioxidant, repairing damaged molecules and cleaning (Baunthiyal et al., 2017).

In recent years, natural antioxidant has gained tremendous interest in preventing and treating various health problems. Ethnomedicinal studies play a pivotal role and have significant attention worldwide contributing as an open door to discover and develop new drugs or other plant-derived antioxidants (Katiyar et al., 2012). Phytochemicals especially polyphenols such as flavonoids are believed to have antioxidant properties. Many studies revealed that total antioxidant activity has a direct relation to the total phenolic content (Zhang et al., 2015). Polyphenol may act as reducing agents, by quenching singlet oxygen, donating hydrogen, chelating compound, and/or by trapping the free radicals (Pandey and Rizvi, 2012), whereas antioxidant properties of flavonoids undergo several ways, namely scavenging radicals, preventing metal transition, and interacting with other antioxidants (Apak et al., 2007).

The previous study on antioxidant activities of selected medicinal plant utilized for liver diseases medication by ethnic traditional healers in Indonesia showed that methanolic extract of $M$. subpeltata and $B$. racemosa leaves had a potential antioxidant property even though its $\mathrm{IC}_{50}$ is still inferior to the $\mathrm{L}-(+)$-ascorbic acid as reference standard (Widodo et al., 2019). However, there are scarce reports about the pharmacological properties particularly antioxidant activity of these plants. Fractionation of methanolic extract using solvents with different polarity could facilitate the grouping of compounds according to its polarity and hence offering different antioxidants ranging from weak to very strong activities. Several studies revealed that fractionation of methanolic extract of plants could get higher antioxidant activities. Rohman et al. (2006) reported that ethyl acetate fraction had the highest antioxidant activities and total phenolics contents of Mengkudu (Morinda citrifolia) fruit than initial methanolic extract and other fractions. The similar results were also obtained by Rohman et al. (2010), Samirana et al. (2017) and Permatasari et al. (2019). Therefore, it is needed to evaluate whether the fractions of the methanolic crude extract of these plants have antioxidant activity to provide basic data on its uses in traditional medicine and/or to explore some new natural antioxidants. The objective of this study was to evaluate the antioxidant activities, phenolics contents, flavonoid contents and their correlations of methanolic crude extract and their fractions of plant's leaves of $B$. racemosa and $M$. subpeltata.

\section{Materials and methods}

\subsection{Materials}

Plant samples of Baccaurea racemosa (Reinw. ex Blume) Müll.Arg. and Macaranga subpeltata K. Schum. \& Lauterb. were collected from Central Java and East Java, respectively. All chemicals used in this study were pro-analytical grade. The solvents and Folin-Ciocalteau's phenol Reagent (FCR), Acetic acid, $\mathrm{AlCl}_{3}, \mathrm{NaCO}_{3}$, $\mathrm{FeCl}_{3} \cdot 6 \mathrm{H}_{2} \mathrm{O}, \mathrm{FeSO}_{4} \cdot 7 \mathrm{H}_{2} \mathrm{O}, \mathrm{L}-(+)$-ascorbic acid were obtained from E. Merck (Darmstadt, Germany). 2,2'diphenyl-2-picrylhydrazyl (DPPH), 2,2'-azino-bis (3ethylbenzthiazoline-6-sulfonic acid) (ABTS), 2,3,5triphenyl-1,3,4-triaza-2-azoniacyclopenta-1,4-diene chloride (TPTZ), Trolox, Gallic acid, Quercetin, and Rutin were purchased from Sigma (Aldrich, USA).

\subsection{Preparation of methanolic extract}

Preparation of methanolic extract was performed according to the previous study (Widodo et al., 2019). Fractionations using various solvents were described in Figure 1. The extract and fraction were air-dried using the oven at $40^{\circ} \mathrm{C}$ until dried (constant weight). The extracts were dissolved and diluted using methanol prior to assay (10 $\mathrm{mg}$ dissolved up to a volume of $1 \mathrm{~mL}$ ).

\subsection{Determination of total phenolic content}

The total phenolic content (TPC) was performed using the method described by Cicco et al. (2009) with a minor adjustment. The final condition of the test solution was: $40 \mu \mathrm{g}$ extract, $4 \%$ methanol, $10 \% \mathrm{FCR}$, and $5 \%$ $\mathrm{CaCO}_{3}$ in the total volume reaction of $1.0 \mathrm{~mL}$. A-40 $\mu \mathrm{L}$ of plant extract was completely mixed with $360 \mu \mathrm{L}$ of $\mathrm{dH}_{2} \mathrm{O}$ and $100 \mu \mathrm{L}$ of FCR and left for 2 mins. The reaction was then added and homogeneously mixed with $500 \mu \mathrm{L}$ of $10 \% \mathrm{CaCO}_{3}$ and left for 20 mins at $40^{\circ} \mathrm{C}$ in the incubator afterward. The absorbance at $732 \mathrm{~nm}$ of $150 \mu \mathrm{L}$ test solution was measured. Gallic acid used as standard reference was prepared at series methanolic dilutions of $0,5,10,15,20$, and $25 \mu \mathrm{g} / \mathrm{mL}$ to generate linear regression for determining phenolics content of the extract by plotting the absorbance of the samples. TPC is expressed as $\mathrm{mg}$ gallic acid equivalent (GAE)/g of the extract.

\subsection{Determination of total flavonoid content}

The total flavonoid content (TFC) was done using a slight modification of the method described by Li et al. (2013). The samples were diluted with methanol to get a concentration of $1,250 \mu \mathrm{g} / \mathrm{mL}(\mathrm{w} / \mathrm{v})$. The mixture reaction consisted of $100 \mu \mathrm{L}$ sample, $250 \mu \mathrm{L}$ acetate buffer $(\mathrm{pH} 3.8), 150 \mu \mathrm{L}$ of $0.1 \mathrm{M} \mathrm{AlCl}_{3}$ solution (replaced with methanol $150 \mu \mathrm{L}$ for the blank), $350 \mu \mathrm{L}$ ultra-pure $\mathrm{dH}_{2} \mathrm{O}$, and adjusted with methanol to gain a 


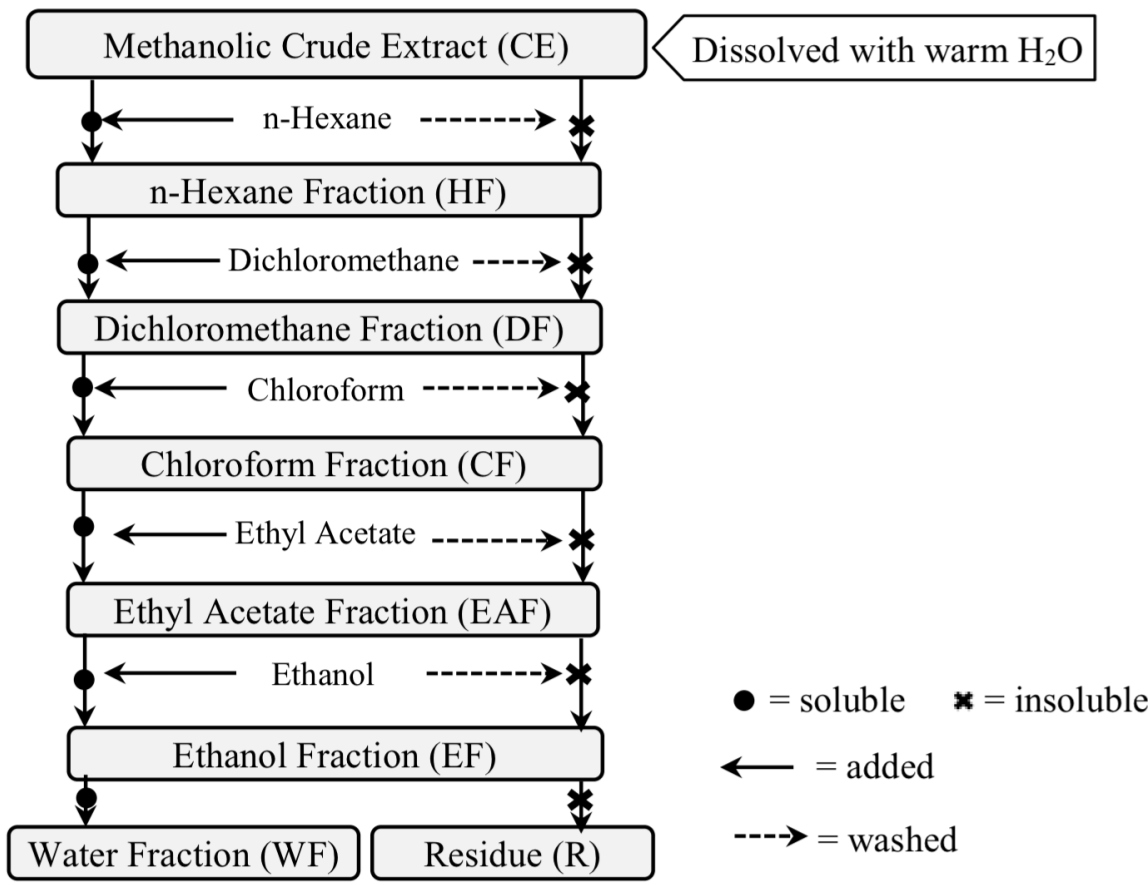

Figure 1. Scheme of the fractionation of methanolic crude extract of M. subpeltata and B. racemosa leaves.

volume of $1,250 \mu \mathrm{L}$. The test solution was placed into the incubator $\left(35^{\circ} \mathrm{C}\right.$ for $\left.30 \mathrm{mins}\right)$. A sample volume of $150 \mu \mathrm{L}$ was pipetted into the microplate prior to absorbance measurement at $398 \mathrm{~nm}$. Rutin was used as a standard reference via generating linear regression using a series of concentrations of $0-90 \mu \mathrm{g} / \mathrm{mL}$ (methanolic dilution). The TFC is expressed as gram rutin equivalents per g extract (mg RE/g).

\subsection{Determination of DPPH Radical Scavenging assay}

DPPH (2,2-diphenyl-1-picrylhydrazyl) was dissolved using methanol to get a concentration of 0.4 $\mu \mathrm{M}$. Plant methanolic extract and its fractions in a volume of the $825 \mu \mathrm{L}$ (with the series final concentrations of $0-150 \mu \mathrm{g} / \mathrm{mL}$ ) and $175 \mu \mathrm{L}$ DPPH (with final concentration $70 \mu \mathrm{M}$ ) were thoroughly mixed. The control was prepared with the same final concentration of sample without addition of DPPH solution. The sample and control reaction tubes were placed in the dark (in the incubator: at $37^{\circ} \mathrm{C}$ for 30 mins). The solution in a volume of $150 \mu \mathrm{L}$ was put into the 96 wells microplate and observed the absorbance using a spectrophotometer at a wavelength of $515 \mathrm{~nm}$. L-(+)ascorbic acid was used as a comparative standard compound. $\mathrm{IC}_{50}$ was calculated using formula $\left[\left(A_{o}-A_{1}\right) /\right.$ $\left.A_{o}\right] \times 100$, where $A_{o}$ : the absorbance of the control and $A_{1}$ : absorbance of the extract or standard).

\subsection{Determination of Trolox Equivalent Antioxidant Capacity (TEAC) assay}

The TEAC value of the extract was determined using the assay described by Dong et al. (2015). The weighed ABTS of $38.4 \mathrm{mg}$ was dissolved completely with $10 \mathrm{~mL}$ of $2.5 \mathrm{mM} \mathrm{K}_{2} \mathrm{~S}_{2} \mathrm{O}_{8}$ then kept in the dark for 12-16 hrs at room temperature. Before applying TEAC assay, the ATBS++ solution should be diluted using methanol to obtain $0.70 \pm 0.02$ absorbance at $743 \mathrm{~nm}$. The sample reaction was done in the total volume of $2.0 \mathrm{~mL}$, which contained the mixture of $50 \mu \mathrm{L}$ of the sample and 1950 $\mu \mathrm{L}$ ATBS + solution (for control reaction, replaced by diluted $2.5 \mathrm{mM} \mathrm{K} \mathrm{S}_{2} \mathrm{O}_{8}$ using methanol in the same volume as the dilution factor of ATBS++ solution). A linear regression of Trolox as standard reference was generated by making a series concentrations of $0-45$ $\mu \mathrm{M}$. The TEAC value was expressed as the Molar Trolox Equivalent per gram extract (M TE/g)

\subsection{Determination of Ferric Reducing Antioxidant Power (FRAP) assay}

The FRAP value reflects the reducing ability of the plant extracts, which estimated using a slight modifications assay of Benzie and Strain (1996). Firstly, $20 \mathrm{mM} \mathrm{FeCl} 3 \cdot 6 \mathrm{H}_{2} \mathrm{O}$ solution, $10 \mathrm{mM} \mathrm{2,4,6-tripyridyl-s-}$ triazine (TPTZ) solution in $40 \mathrm{mM} \mathrm{HCl}$, and acetate buffer $(300 \mathrm{mM}$; pH 3.6) were made to produce the FRAP reagent by mixing those solutions by volume ratio of 1:1:10 respectively. A linear regression was generated using $\mathrm{FeSO}_{4} \cdot 7 \mathrm{H}_{2} \mathrm{O}$ in the final concentration $100-1,000$ $\mu \mathrm{M} / \mathrm{mL}$ applied in $2.0 \mathrm{~mL}$ final volume reaction. The contained $150 \mathrm{~mL}$ extract or $\mathrm{FeSO}_{4} \cdot 7 \mathrm{H}_{2} \mathrm{O}$ mixed with $1,350 \mu \mathrm{L}$ of FRAP reagent. The mixture was then incubated for $30 \mathrm{~min}$ at $37^{\circ} \mathrm{C}$, prior to measuring the absorbance at $595 \mathrm{~nm}$. Quercetin, L-(+)-ascorbic acid were used as the standard reference.

\subsection{Data analysis}

All data represented from the average of triplicate analyses and recorded as mean \pm SD. The data were 
subjected to variance (ANOVA) and correlation analysis using SPSS version 22.

\section{Result and discussion}

B. racemosa and M. subpeltata are among 381 medicinal plants which have been used for liver diseases medication by Indonesia ethnic traditional healers. The activity as an antioxidant considered to be one of the major mechanism underlying their healing utilization (Widodo, Rohman and Sismindari, 2019). The previous study showed that leaves methanolic extract of these two plants had high potential antioxidant activity. The fractionation using different polarity solvent to the crude methanolic extract (CE) showed that they had the same tone in the yield percentage except for those in water fraction and the residue (Table 1).

Table 1. The yield of fraction crude methanolic extract leaves, Total Flavonoid Content and Total Phenolic Content of $B$. racemosa and M. subpeltata

\begin{tabular}{cccc}
\hline $\begin{array}{c}\text { Extracts/ } \\
\text { Fractions }\end{array}$ & $\begin{array}{c}\text { Yield } \\
(\%)\end{array}$ & $\begin{array}{c}\text { TFC } \\
(\mathrm{mg} \mathrm{RE} / \mathrm{g})\end{array}$ & $\begin{array}{c}\text { TPC } \\
(\mathrm{mg} \mathrm{GAE} / \mathrm{g})\end{array}$ \\
\hline B. racemosa & & & \\
CE & 17.26 & $21.39 \pm 3.64^{\mathrm{a}}$ & $237.58 \pm 16.71^{\mathrm{f}}$ \\
HF & 4.3 & $13.82 \pm 2.00^{\mathrm{a}}$ & $20.28 \pm 0.11^{\mathrm{a}}$ \\
DF & 0.72 & $53.25 \pm 9.71^{\mathrm{bc}}$ & $93.53 \pm 7.21^{\mathrm{b}}$ \\
CF & 0.18 & $58.96 \pm 1.61^{\mathrm{c}}$ & $136.23 \pm 8.00^{\mathrm{c}}$ \\
EAF & 2.07 & $179.86 \pm 3.57^{\mathrm{h}}$ & $412.50 \pm 18.43^{\mathrm{h}}$ \\
EF & 2.76 & $44.26 \pm 1.74^{\mathrm{b}}$ & $423.42 \pm 18.70^{\mathrm{h}}$ \\
WF & 0.74 & $18.09 \pm 0.81^{\mathrm{a}}$ & $284.83 \pm 10.4^{\mathrm{g}}$ \\
R & 6.4 & $17.21 \pm 1.14^{\mathrm{a}}$ & $70.76 \pm 6.63^{\mathrm{b}}$ \\
M. subpeltata & & & \\
CE & 14.39 & $74.70 \pm 0.36^{\mathrm{d}}$ & $204.25 \pm 2.22^{\mathrm{e}}$ \\
HF & 3.12 & $52.76 \pm 1.12^{\mathrm{bc}}$ & $77.58 \pm 4.03^{\mathrm{b}}$ \\
DF & 1.39 & $105.15 \pm 13.56^{\mathrm{e}}$ & $177.91 \pm 8.24^{\mathrm{d}}$ \\
CF & 0.12 & $131.06 \pm 0.49^{\mathrm{f}}$ & $172.62 \pm 8.19^{\mathrm{d}}$ \\
EAF & 2.61 & $203.28 \pm 9.10^{\mathrm{i}}$ & $619.69 \pm 31.49^{\mathrm{i}}$ \\
EF & 0.53 & $149.33 \pm 6.02^{\mathrm{g}}$ & $432.75 \pm 12.66^{\mathrm{h}}$ \\
WF & 6.24 & $52.42 \pm 2.42^{\mathrm{bc}}$ & $254.20 \pm 9.58^{\mathrm{f}}$ \\
R & 0.32 & $123.72 \pm 3.29^{\mathrm{f}}$ & $284.08 \pm 10.25^{\mathrm{g}}$ \\
\hline
\end{tabular}

Values followed by the same alphabet in a column did not differ significantly at $\mathrm{p}=0.05$ according to Duncan's Multiple Range Test (DMRT).

Non-polar solvents such as hexane, dichloromethane, and chloroform usually elute lipoidal material from crude extract (Dai and Mumper, 2010), hence the nonpolar fractions of hexane fraction (HF), dichloromethane fraction (DF), and chloroform fraction (CF) contained less phenolic compounds (PC) than that the CE. The color of the HF was darker green (data not shown) than other fractions since hexane can dissolve chlorophyll from the crude extract. Chlorophyll and its derivates exhibit to have low antioxidant activity when measured by DPPH assay, considered that the action of chlorophyll might be involved to metal chelation (Hsu et al., 2013) rather than hydrogen donation (Lanfer-Marquez et al.,
2005). The solubility of phenol compounds into a solvent is determined by activity coefficient as the main thermodynamic factor which governs their tendency to be solubilized, diffused, or transferred into solvents. The stereochemistry of phenols (the polar and the non-polar fragment inside the molecules) and the intermolecular forces (mainly hydrogen bonds) occurred between PCs and the solvents determine their solubility (Galanakis et al., 2013).

In the present study, TPC of ethyl acetate fraction (EAF) and ethanol fraction (EF) of M. subpeltata and $B$. racemosa were higher than that of other fractions. Polar and semi-polar solvents are suitable for extracting polyphenols in plant matrices, the most convenient solvents are aqueous mixtures containing ethanol, methanol, acetone, and ethyl acetate (Do et al., 2014). The UNIFAC model for calculating the activity coefficient of PCs indicate that intermediate polarity solvents (alcohols and acetone) are more preferred rather than more polar (e.g., water) or less polar solvents (Galanakis et al., 2013). In general, alcohol represented the highest solubility for PCs which had the shortest carbon chain (Boas, 2017). Ethanol dissolved the highest PCs from the CE of B. racemosa comparable to that of ethyl acetate. Ethyl acetate also is the solvent of choice for extracting PCs from CE of M. subpeltata. The PCs comprise many substances classes of simple phenols, coumarins, lignins, lignans, condensed and hydrolyzable tannins, phenolic acids and flavonoids, which all possess an aromatic ring bearing at least one hydroxyl groups (Khoddami et al., 2013).

The solvents usually used to extract flavonoids are methanol, ethanol, acetone, water or mixtures of these solvents (Khoddami et al., 2013). The solubility of flavonoid compounds is varied depending on the complex nature of compounds, the selected solvents, and the system such as thermodynamic properties, ability to form hydrogen bonds with the surrounding solvent, solvent polarity, temperature, and $\mathrm{pH}$ value. The glycosylated flavonoids (such as in rutin and isoquercitrin) tend to have a lower melting point, higher enthalpy of fusion and lower solubility in polar solvents compared to those of corresponding aglycons. The solubility of flavonoid compounds (FCs) has no direct correlation to their thermodynamic properties in contrast to those of PCs. Moreover, the solubility of FCs is also influenced by a torsion angle $\theta$ (OC2C1' $\mathrm{C} 6$ ') that considered to be related to the $\mathrm{C} 2-\mathrm{C} 3$ bonding, in which the $\mathrm{C} 2-\mathrm{C} 3$ single bond instead of double bond would increase a torsion angle $\theta$ that contributes to higher solubility in polar solvents (Chebil et al., 2007).

Table 2 compiles DPPH radical scavenging assay 
expressed by inhibition concentration at $50 \%$ of DPPH radicals known as $\mathrm{IC}_{50}$, Trolox Equivalent Antioxidant Capacity (TEAC), and Ferric Reducing Antioxidant Power (FRAP) Crude Extracts and its fractions of $B$. racemosa and $M$. subpeltata. EAF and EF showed prominently radical scavenging activity as showed by the lower $\mathrm{IC}_{50}$ value of DPPH radical scavenging activity assay applied to $M$. subpeltata and $B$. racemosa, respectively. The lower concentration of the $\mathrm{IC}_{50}$ value, the highest capacity of the sample to scavenge DPPH radical. The EAF of $M$. subpeltata showed the most active in scavenging DPPH radical even compared to the activity of L-(+)-ascorbic acid. Due to its simplicity and high accuracy that makes the DPPH radical scavenging assay becomes the most extensively applied techniques to evaluate antioxidant activity (Nur Alam et al., 2012). DPPH scavenging assay posses some other advantages namely DPPH free radical reacts significantly with radical scavengers, DPPH is unaffected by certain side reactions of polyphenols, such as metal ion chelation and enzyme inhibition. In addition, the results of the assay have a high correlation to other antioxidant assays (Babbar et al., 2014). Consistent with the result of the present study that DDPH assay correlated to the TPC dan TEAC values indicated that PCs are responsible for the antiradical activity.

Table 2. The $\mathrm{IC}_{50}$ DPPH scavening activity, Trolox Equivalen Antioxidant Capacity (TEAC), and Ferric Reducing Antioxidant Power (FRAP) Crude Extracts and their fractions of of B. racemosa and M. subpeltata

\begin{tabular}{cccc}
\hline Fractions & $\begin{array}{c}\mathrm{IC}_{50} \\
(\mu \mathrm{g} / \mathrm{mL})\end{array}$ & $\begin{array}{c}\text { TEAC } \\
(\mathrm{mg} \mathrm{TE} / \mathrm{g})\end{array}$ & $\begin{array}{c}\text { FRAP } \\
\left(\mathrm{mM} \mathrm{Fe}^{2+} / 10 \mathrm{mg}\right)\end{array}$ \\
\hline B. racemosa & & & \\
CE & $4.30 \pm 0.31$ & $354.88 \pm 0.55$ & $900.18 \pm 15.41$ \\
HF & $131.21 \pm 2.81$ & $5.31 \pm 0.91$ & $12.61 \pm 1.40$ \\
DF & $11.26 \pm 0.14$ & $127.52 \pm 6.98$ & $231.70 \pm 1.40$ \\
CF & $6.70 \pm 0.02$ & $200.64 \pm 4.91$ & $404.00 \pm 2.68$ \\
EAF & $3.24 \pm 0.01$ & $395.52 \pm 3.01$ & $945.14 \pm 5.28$ \\
EF & $2.42 \pm 0.08$ & $532.44 \pm 6.38$ & $1221.48 \pm 41.19$ \\
WF & $4.25 \pm 0.01$ & $311.02 \pm 1.74$ & $784.10 \pm 3.41$ \\
R & $11.32 \pm 0.38$ & $133.36 \pm 1.69$ & $610.84 \pm 12.87$ \\
M. subpeltata & & & \\
CE & $4.00 \pm 0.15$ & $297.59 \pm 0.94$ & $601.46 \pm 16.90$ \\
HF & $19.03 \pm 0.83$ & $49.56 \pm 0.84$ & $205.36 \pm 1.61$ \\
DF & $7.92 \pm 0.04$ & $198.62 \pm 1.72$ & $438.51 \pm 2.14$ \\
CF & $10.48 \pm 0.03$ & $163.79 \pm 1.97$ & $468.13 \pm 7.43$ \\
EAF & $1.98 \pm 0.03$ & $703.21 \pm 13.99$ & $2007.69 \pm 21.55$ \\
EF & $3.51 \pm 0.13$ & $464.77 \pm 29.62$ & $1251.06 \pm 22.14$ \\
WF & $5.12 \pm 0.25$ & $331.08 \pm 3.57$ & $815.26 \pm 13.99$ \\
R & $4.39 \pm 0.10$ & $332.95 \pm 3.06$ & $719.63 \pm 16.89$ \\
L-(+)-ascorbic & $2.10 \pm 0.08$ & & $2,031.88 \pm 51.74$ \\
acid & & & \\
\hline CE $=$ & & &
\end{tabular}

$\mathrm{CE}=$ crude methanolic extract; $\mathrm{HF}=$ hexane fraction; $\mathrm{DF}=$ dichloromethane fraction; $\mathrm{CF}=$ chloroform fraction; $\mathrm{EAF}=$ ethyl acetate fraction; $\mathrm{EF}=$ ethanol fraction; $\mathrm{WF}=$ water fraction; $\mathrm{R}=$ residue.
The ferric reducing activity power (FRAP) value reflects the antioxidant activity of the samples by measuring their ability to transform $\mathrm{Fe}^{3+}$-TPTZ complex (colorless/slightly brownish) to $\mathrm{Fe}^{2+} /$ ferrous form (blue) in acidic solution. The higher the reductive capacity of extracts or compounds, the more intense blue color develops, which can be monitored by absorbance measurement at $595 \mathrm{~nm}$ (Benzie and Strain, 1996).

Table 3 exhibits the Pearson correlation $(r)$ among total phenolics content (TPC), total flavonoid contents (TFC), $\mathrm{IC}_{50}$ of DPPH radical scavenging activity, Trolox equivalent antioxidant capacity (TEAC), and ferric reducing activity power (FRAP). TPC values were moderately correlated with TFC $(\mathrm{r}=0.680, \mathrm{p}<0.001)$, suggested that $46.24 \%\left(r^{2}\right)$ variation in the TPC was due to TFC. Recent studies have revealed that the TPC was associated with the antioxidant activity (Teixeira et al., 2017; Li et al., 2018). TPC showed a highly significant correlation with FRAP and TEAC values which indicated that the main component of PCs from fractions enabled to transfer their electron to neutralize free radical and to reduce the metal ion. TEAC and FRAP are recognized as electron transfer based methods. TPCs fractions of $M$. subpeltata showed more responsible for the antioxidant activity than $B$. racemosa as shown by higher $\mathrm{R}^{2}$ value for its correlation with both FRAP and TEAC. Figure 2 reveals the correlations between total phenolics contents (TPC) and Trolox equivalent antioxidant capacity (TEAC) values of $B$. racemosa (A) and $M$. subpeltata (B) along with the correlations between TPC value and FRAP values of B. racemosa (C) and M. subpeltata (D).

Table 3. Pearson correlation (r) among TPC, TFC, $\mathrm{IC}_{50}$ of DPPH radical scavenging activity, TEAC, and FRAP

\begin{tabular}{lcccc}
\hline Variables & TPC & TFC & IC $_{50}$ DPPH & TEAC \\
\hline TFC & $0.680^{* *}$ & & & \\
IC $_{50}$ DPPH & $-0.464^{* *}$ & $-0.338^{*}$ & & \\
TEAC & $0.968^{* *}$ & $0.562^{* *}$ & $-0.515^{* *}$ & \\
FRAP & $0.949^{* *}$ & $0.567^{* *}$ & $-0.480^{* *}$ & $0.967^{* *}$ \\
\hline
\end{tabular}

$* *=$ Correlation significant at the 0.01 level (2-tailed), $*=$ Correlation significant at the 0.05 level (2-tailed). TPC $=$ total phenolics contents; TFC $=$ Total flavonoid content; $\mathrm{DPPH}=2,2$ '-diphenyl-1-picrylhydrazyl; TEAC $=$ Trolox equivalent antioxidant capacity.

The TFC showed lower linearity correlation to both DPPH and TEAC assays than that TPC may due to the radical scavenging capability of flavonoids vary depend on the type, structure and the position of hydroxyl groups. In addition flavonoids in plants generally present as glycosides, and many as 3-O-glycosides which found to have lower TEAC and DPPH value than their corresponding aglycones (Csepregi et al., 2016). 

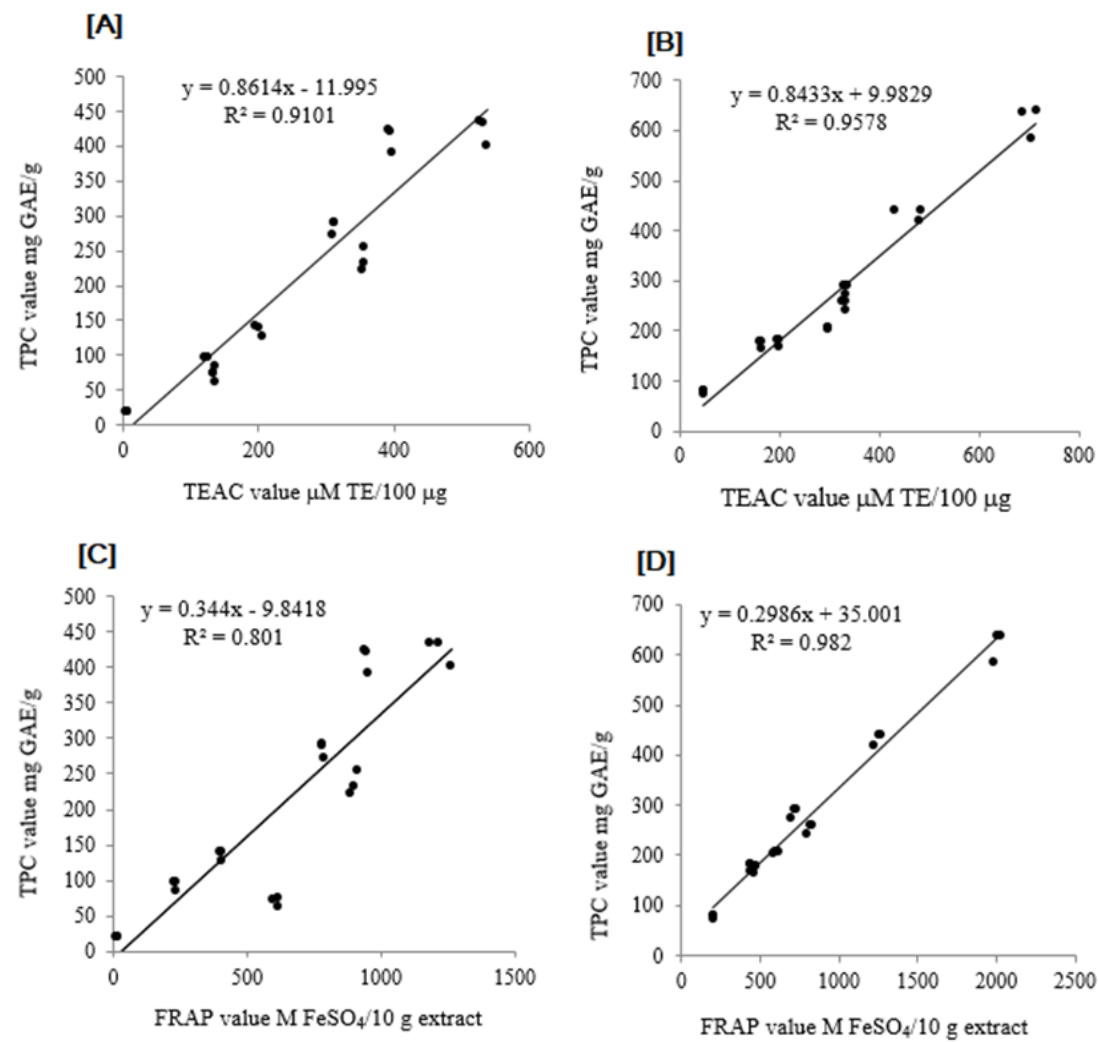

Figure 2. Correlations between total phenolics contents (TPC) and Trolox equivalent antioxidant capacity (TEAC) values of B. racemosa (A) and M. subpeltata (B); Correlations between TPC value and FRAP values of B. racemosa (C) and $M$. subpeltata $(\mathrm{D})$.

\section{Conclusion}

Two methanolic extracts of leaves of B. racemosa and M. subpeltata has been fractionated and the fractions obtained were subjected to antioxidant assay. The crude methanolic extract and its fractions of M. subpeltata contained higher of total phenolics content and total flavonoid contents, and also demonstrated higher antioxidant capacity, than those of $B$. racemosa. The ethyl acetate fraction of $M$. subpeltata has better DPPH radical scavenging activity than $\mathrm{L}-(+)$-ascorbic acid as a positive control. The high antioxidant activities and phenolics contents make both the plant extracts to be developed as a food supplement.

\section{Conflict of Interest}

Authors declare no conflict of interest.

\section{Acknowledgement}

The publication of this manuscript was supported by the Ministry of Research and Higher Education, Republic of Indonesia for financial support through scheme World Class Research 2019 with contract number of 1973/UN1.DITLIT/DIT-LIT/LT/2019.

\section{References}

Ali, K., Wilkes, M.A. and Roberts, T.H. (2013). Techniques for analysis of plant phenolic compounds. Molecules, 18(2), 2328-2375; https:// doi.org/10.3390/molecules18022328

Apak, R., Güçlü, K., Demirata, B., Özyürek, M., Çelik, S.E., Bektaşoğlu, B., Berker, K.I. and Özyurt, D. (2007). Comparative evaluation of various total antioxidant capacity assays applied to phenolic compounds with the CUPRAC assay. Molecules, 12 (7), 1496-1547. https://doi.org/10.3390/12071496

Babbar, N., Oberoi, H.S., Sandhu, S.K. and Bhargav, V.K. (2014). Influence of different solvents in extraction of phenolic compounds from vegetable residues and their evaluation as natural sources of antioxidants. Journal of Food Science and Technology, 51(10), 2568-2575. https:// doi.org/10.1007/s13197-012-0754-4

Baunthiyal, M., Singh, V. and Dwivedi, S. (2017). Insights of antioxidants as molecules for drug discovery. International Journal of Pharmacology, 13(7), $\quad$ 874-889. https://doi.org/10.3923/ ijp.2017.874.889

Benzie, I.F.F. and Strain, J.J. (1996).The ferric reducing ability of plasma (FRAP) as a measure of "Antioxidant Power": The FRAP assay. Analytical Biochemistry, 239(1), 70-76. https://doi.org/10.1006/ abio.1996.0292

Boas, S.A.M.V. (2017). Studies on the Solubility of Phenolic Compounds. Portugal: Instituto Politécnico de Bragança, MSc. Thesis. 
Cacciapuoti, F. (2016). Oxidative Stress as "Mother" of Many Human Diseases at Strong Clinical Impact. Journal of Cardiovascular and Medical Cardiology, 3(1), 001-006. https://doi.org/10.17352/24552976.000020

Chebil, L., Humeau, C., Anthoni, J., Dehez, F., Engasser, J-C. and Ghoul, M. (2007). Solubility of Flavonoids in Organic Solvents. Journal of Chemical Engineering Data, 52, 1552-1556. https:// doi.org/10.1021/je7001094

Cicco, N., Lanorte, M.T., Paraggio, M., Viggiano, M. and Lattanzio, V.A. (2009). Reproducible, rapid and inexpensive Folin-Ciocalteu micro-method in determining phenolics of plant methanol extracts. Microchemical Journal, 91(1), 107-110. https:// doi.org/10.1016/j.microc.2008.08.011

Csepregi, K., Neugart, S., Schreiner, M. and Hideg, E. (2016). Comparative evaluation of total antioxidant capacities of plant polyphenols. Molecules, 21(2), 208. https://doi.org/10.3390/molecules21020208

Do, Q.D., Angkawijaya, A.E., Tran-Nguyen, P.L., Huynh, L.H., Soetaredjo, F.E., Ismadji, S. and Ju, YH. (2014). Effect of extraction solvent on total phenol content, total flavonoid content, and antioxidant activity of Limnophila aromatica. Journal of Food and Drug Analysis, 22(3), 296-302. https://doi.org/10.1016/j.jfda.2013.11.001

Dong, J.W., Cai, L., Xing, Y., Yu, J. and Ding, Z.T. (2015). Re-evaluation of ABTS·+ assay for total antioxidant capacity of natural products. Natural Products Communications, 10(12), 2169-72. https:// doi.org/10.1177/1934578X1501001239

Galanakis, C.M., Goulas, V., Tsakona, S., Manganaris, G.A. and Gekas, V. (2013). A knowledge base for the recovery of natural phenols with different solvents. International Journal of Food Properties, 16(2), 382-396. https:// doi.org/10.1080/10942912.2010.522750

Gangwar, M., Gautam, M.K., Sharma, A.K., Tripathi, Y.B., Goel, R.K. and Nath, G. (2014). Antioxidant capacity and radical scavenging effect of polyphenol rich Mallotus philippenensis fruit extract on human erythrocyte: an in vitro study. The Scientific World Journal, 2014, 1-12. 1ttps:// doi.org/10.1155/2014/279451

Hsu, C-Y., Chao, P-Y., Hu, S-P. and Yang, C-M. (2013). The antioxidant and free radical scavenging activities of chlorophylls and pheophytins. Food and Nutrition Sciences, 4, 1-8. https://doi.org/10.4236/ fns.2013.48A001

Katiyar, C., Gupta, A., Kanjilal, S. and Katiyar, S. (2012). Drug discovery from plant sources: An integrated approach. $A Y U, 33(1), 10-19$. https:// doi.org/10.4103/0974-8520.100295

Lanfer-Marquez, U.M., Barros, R.M.C. and Sinnecker, P. (2005). Antioxidant activity of chlorophylls and their derivatives. Food Research International, 38(89), $\quad 885-891 . \quad$ https://doi.org/10.1016/ j.foodres.2005.02.012

Li, G., Yu, S., Zhou, Y-H. and Chen Q-F. (2013). Spectrophotometric Determination of Flavonoids Content in Leaves of Fagopyrum cymosum Complex. Asian Journal of Chemistry, 25(13), 75757578. https://doi.org/10.14233/ajchem.2013.15265

Li, Z., Lee, H.W., Liang, X., Liang, D., Wang, Q., Huang, D. and Ong, C.N. (2018). Profiling of phenolic compounds and antioxidant activity of 12 cruciferous vegetables. Molecules, 23(5), 1139. https://doi.org/10.3390/molecules23051139

Mamta, M.K., Dhillon, G.S., Brar, S.K. and Verma, M. (2014). Antioxidants. In Brar, S., Dhillion, G. and Soccol, C. (Eds.). Biotransformation of Waste Biomass into High Value Biochemicals. New York: Springer. https://doi.org/10.1007/978-1-4614-80051_6

Matschke, V., Theiss, C. and Matschke, J. (2019). Oxidative stress: the lowest common denominator of multiple diseases. Neural Regeneration Research, 14 (2), 238-41. https://doi.org/10.4103/16735374.244780

Pandey, K.B. and Rizvi, S.I. (2012). Ferric reducing and radical scavenging activities of selectec important polyphenols present in foods. International Journal of Food Properties, 15(3), 702-708. https:// doi.org/10.1080/10942912.2010.498547

Permatasari, L., Riyanto, S. and Rohman, A. (2019). Baccaurea racemosa (Reinw. ex Blume) Müll. Arg. pulp: a potential natural antioxidant. Food Research, 3(6), 713 - 719. https://doi.org/10.26656/fr.2017.3 (6). 165

Rohman, A., Riyanto, S. and Utari, U. (2006). Antioxidant activity and total phenolic content of ethyl acetate extract of Mengkudu (Morinda citrifolia L) fruit, Indonesian Journal of Pharmacy, $17(2), 136-142$.

Rohman, A., Riyanto S., Yuniarti N., Saputra W.R., Utami, R., and Mulatsih, W. (2010). Antioxidant activity, total phenolic, and total flavonoid of extracts and fractions of red fruit (Pandanus conoideus Lam). International Food Research Journal, 17, 97-106.

Samirana, P.O., Susidarti, R.A. and Rohman, A. (2017). Isolation and 2,2'-diphenyl-1-picrylhydrazyl radical scavenging activity of active compound from Jujube 
tree (Zizyphus mauritiana Auct. non Lamk.). International Journal of Food Properties, 20(Suppl.

2), 1523-1529.

https://

doi.org/10.1080/10942912.2016.1233427

Teixeira, T.S., Vale, R.C., Almeida, R.R., Ferreira, T.P.S. and Guimarães, L.G.L. (2017). Antioxidant potential and its correlation with the contents of phenolic compounds and flavonoids of methanolic extracts from different medicinal plants. Revista Virtual Quimica, 9, 1546-1559. https:// doi.org/10.21577/1984-6835.20170090

Widodo, H., Sismindari, S., Asmara, W. and Rohman, A. (2019). Antioxidant activity, total phenolic and flavonoid contents of selected medicinal plants used for liver diseases and its classification with chemometrics. Journal of Applied Pharmaceutical Sciences, 9(6), 99-105. https://doi.org/10.7324/ JAPS.2019.90614.

Widodo, H., Rohman, A. and Sismindari, S. (2019). Permanfaatan Tumbuhan Famili Fabaceae untuk Pengobatan Penyakit Liver oleh Pengobat Tradisional Berbagai Etnis di Indonesia. Media Penelitian and Pengembangan Kesehatan, 29(1), 6588.

Zhang, Y-J., Gan, R-Y., Li, S., Zhou, Y., Li, A-N., Xu, D-P. and Li, H-B. (2015). Antioxidant Phytochemicals for the Prevention and Treatment of Chronic Diseases. Molecules, 20(12), 21138-21156. https://doi.org/10.3390/molecules201219753 